\title{
HUBUNGAN TERAPI SENAM YOGA TERHADAP INSOMNIA DI KELOMPOK SENAM YOGA ASTHMA SURABAYA
}

\author{
Setiana Andarwulan ${ }^{1)}$, Annah Hubaedah ${ }^{2)}$ \\ Fakultas Sains Kesehatan (Program Studi D III Kebidanan) \\ Universitas PGRI Adi Buana Surabaya, Surabaya, Indonesia \\ email: setianaandarwulan@unipasby.ac.id
}

\begin{abstract}
Abstrak
Perubahan usia yang terjadi menyebabkan kemampuan fisik menjadi menurun salah satu penyebabnya adalah penurunan kekuatan fisik dalam fase tidur lansia. Cara pengobatan yang ditempuh dengan penggunaan konsumsiobat penenang dengan harapan cepat tertidur, namun mengkonsumsi obat jangka panjang dapat memberikan efek kimia di dalam tubuh, sehingga pemakaian obat-obatan terbuat dari bahan alam menjadi salah satu solusi dalam menunkan insomnia. Alternatif lainnya dengan melakukan olahraga. Salah satu olahraga yang direkomendasikan adalah yoga. Yoga yang dilakukan secara rutin dapat digunakan dalam menurunkan insomnia. Metode yang digunakan dalam penelitian adalah preeksperimental, dengan uji statistik yang digunakan yaitu uji chisquare. Hasil penelitian yang di dapatkan melalui perhitungan SPSS.20 menunjukkan nilai Asymp. Sig ( 2-sided) sebesar 0,044. Nilai hasil uji statistik ini lebih kecil dari $\alpha=0,05$. Sehingga dari hasil penelitian dapat disimpulkan adanya hubungan yang signifikan antara terapi senam yoga yang rutin terhadap insomnia. Terapi senam yoga yang diberikan secara rutin secara efektif dalam menurunkan insomnia pada lansia.
\end{abstract}

Kata kunci: terapi, senam, yoga, insomnia, lansia

\begin{abstract}
The age changes decreased physical abilities is one of the causes of decreasing in physical strength in the sleep phase of the elderly. The method of treatment is the use of sedative drugs to lead falling asleep quickly, but taking long-term drugs can have a chemical effect in the body, so the use of drugs made from natural ingredients is one solution in reducing insomnia. Another alternative is to do sports. One of the recommended sports is yoga. Yoga that is done regularly can be used to reduce insomnia. The method used in this research is pre-experimental, with the statistical test used is the chi-square test. The research results obtained through the calculation of SPSS.20 show the value of Asymp. Sig (2-sided) is 0.044. The value of this statistical test result is smaller than $\alpha=0.05$. So from the results of the study, it can be concluded that there is a significant relationship between routine yoga therapy toward insomnia. Yoga exercise therapy that is given regularly is effective in reducing insomnia in the elderly.
\end{abstract}

Keywords: therapy, gymnastics, yoga, insomnia, elderly

\section{PENDAHULUAN}

Besarnya jumlah penduduk lansia di Indonesia pada masa depan membawa dampak postif maupun negatif. Berdampak positif, apabila penduduk lansia berada dalam keadaan sehat, aktif, dan produktif. Menurut Peraturan Pemerintah Republik Indonesia Nomor 43 Tahun 2004, lanjut usia adalah seseorang yang telah mencapai usia 60 (enam puluh) tahun ke atas. Komposisi penduduk tua bertambah dengan pesat baik di negara maju maupun negara berkembang. Hal ini disebabkan oleh penurunan angka fertilitas (kelahiran) dan mortalitas (kematian), serta peningkatan angka harapan hidup (life expentancy) yang mengubah struktur penduduk secara keseluruhan. Faktor- faktor yang dapat mempengaruhi penuaan tersebut yaitu: peningkatan gizi, sanitasi, pelayanan kesehatan hingga kemajuan tingkat pendidikan dan sosial ekonomi yang semakin membaik. Secara global populasi lansia diprediksi terus mengalami peningkatan. (Wicaksono, 2019) (Selo, Candrawati and Putri, 2017). Data Kemenkes RI memprediksikan bahwa pada tahun 2015, Indonesia sudah memasuki era penduduk menua (ageing population). Hal tersebut dikarenakan jumlah penduduk yang berusia 60 tahun keatas (penduduk lansia) melebihi angka 7\%. Perubahan usia yang terjadi menyebabkan kemampuan fisik menjadi menurun. Kemampuan fisik yang menurun salah satunya ditunjukkan oleh 
penurunan kekuatan fisik dalam fase tidur pada lansia (Kemenkes RI, 2017).

Dalam membentuk lansia yang sehat, tentunya erat hubungannya dengan pola hidup sehat salah satunya adalah menjaga pola tidur yang cukup. Kualitas tidur lansia yang berubah yaitu tidur, Rapid Eye Movement/REM mulai menurun (S, 2019) (Luik et al., 2015). Menurunnya tingkat progresif pada tahap Non Rapid Eye Movement REM 3 dan 4. Pada tahapan selanjutnya akan terus menurun sampai dengan tidak ada jarak dengan REM 4. Berubahnya struktur saat tidur pada lansia disebabkan oleh sistem saraf di perifer (SSP) yang imbasnya membawa sensitivitas dengan waktu dalam menstabilkan irama sirkardian (Suzuki, Miyamoto and Hirata, 2017). Hal ini menimbulkan berbagai dampak negatif, antara lain dapat merusak mood lansia, merasa lemas, tidak segar saat melakukan aktivitas, dan meningkatkan resiko jatuh karena berkurangnya tingkat konsentrasi pada lansia (Ilmi, Saraswati and Hartono, 2019).

Pemenuhan kebutuhan tidur merupakan hal yang sering terjadi. Sebuah survei epidemiologi yang dilakukan di Jepang melaporkan prevalensi insomnia sebesar $21,4 \%$ ketika insomnia didefinisikan mencakup setidaknya salah satunya kesulitan memulai tidur $(8,3 \%)$, mempertahankan tidur $(15,0 \%)$ atau bangun pagi $(8,0 \%)$. Dari setengah orang dewasa yang lebih tua menderita insomnia dan subjek ini sering tidak diobati. Insiden tahunan insomnia pada orang tua dilaporkan mencapai 5-8\%. Dalam studi epidemiologi subjek sebanyak 28.714 responden. (Kamel and Gammack, 2006)(Sutton, 2014). Prevalensi mengantuk pada siang hari yang berlebihan merupakan kejadian yang sering dialami oleh lansia hingga mencapai 2,5\%. (Hafizah et al., 2018) Sehingga dibutuhkan suatu pengobatan yang tidak memiliki efek samping jangka panjang untuk membantu dalam memperbaiki pola tidur (Setiawan, Yunani and Eni, 2014).

\section{METODE PENELITIAN}

Metode penelitian yang digunakan dalam penelitian ini memakai penelitian kuantitatif. Desain penelitian menggunakan deskriptif korelasi. Dalam penelitian ini peneliti mencoba menghubungkan antara variabel bebas dengan variabel terikat. Dengan menggunakan desain penelitian pre eksperimen, yaitu bentuk penelitian yang memanipulasi variabel bebas yang ikut dalam memberikan pengaruh pada variabel terikat. Jenis penelitian eksperimen yang diambil adalah one group pre test post test. Peneliti sebelumnya memberikan pre test kepada kelompok perlakuan. Kemudian peneliti memberikan perlakuan. Setelah selesai peneliti memberikan post test (Sujarweni, 2015) (Purnomo and Bramantoro, 2018). Populasi dalam penelitian adalah semua lansia yang tergabung mulai bulan Januari - Maret 2020 dalam kelompok Senam Ashma Yoga Surabaya sebanyak 30 orang. Pengambilan sampel yang digunakan adalah total sampling. Peneliti melakukan pengukuran tentang insomnia dengan mengunakan kuesioner PSQI. Instrumen yang digunakan dalam penelitian ini adalah Pittsburgh Sleep Quality Index (PSQI) dengan nilai cronbach's alpha0,707, yang dikembangkan oleh Buysse, Reynolds, Monk, Berman, \& Kupfer (1989) di Universitas Pittsburgh, Amerika untuk mengukur kualitas tidur yang terdiri dari tujuh komponen, yaitu kualitas tidur subjektif, latensi tidur, durasi tidur, gangguan tidur, efisiensi tidur, penggunaan obat tidur, dan fungsi tidur pada siang hari yang kemudian dianalisis dengan menggunakan SPSS untuk mengetahui hasilnya (Sukmawati and Putra, 2019).

\section{HASIL DAN PEMBAHASAN}

Berikut disajikan karateristik data insomnia responden pre test dan post test di kelompok Senam Yoga Asthma Surabaya.

Tabel 1. Karateristik Data Insomnia Responden Pre Test dan Post Test di Kelompok Senam Yoga Asthma Surabaya

\begin{tabular}{lcccc}
\hline \multirow{2}{*}{ Insomnia } & \multicolumn{2}{c}{ Pre Test } & \multicolumn{2}{c}{ Post test } \\
\cline { 2 - 5 } & Jumlah Responden & Persentase & Jumlah Responden & Persentase \\
& $(\mathrm{N})$ & $(\%)$ & $(\mathrm{N})$ & $(\%)$ \\
\hline Baik & 3 & 10 & 19 & 63,3 \\
Buruk & 27 & 90 & 11 & 36,7 \\
\hline Total & $\mathbf{3 0}$ & $\mathbf{1 0 0 , 0}$ & $\mathbf{3 0}$ & $\mathbf{1 0 0 , 0}$ \\
\hline
\end{tabular}

Berdasarkan tabel 1 menunjukkan bahwa dari 30 responden yang dilakukan pre test terapi senam yoga, yang memiliki insomnia buruk sebanyak 27 responden (90\%). Selanjutnya setelah diberikan terapi yoga secara rutin dan dilakukan post test didapatkan yang mengalami gangguan tidur atau insomnia buruk menurun menjadi 11 responden $(36,7 \%)$. 
Tabel 2. Karateristik Data Insomnia Responden Pre Test dan Post Test di Kelompok Senam Yoga Asthma Surabaya

\begin{tabular}{|c|c|c|c|c|c|c|}
\hline \multirow{3}{*}{ Senam Yoga } & \multicolumn{4}{|c|}{ Insomnia } & \multirow{2}{*}{\multicolumn{2}{|c|}{ Total }} \\
\hline & \multicolumn{2}{|c|}{ Baik } & \multicolumn{2}{|c|}{ Buruk } & & \\
\hline & $\mathrm{N}$ & $\%$ & $\mathrm{~N}$ & $\%$ & $\mathrm{~N}$ & $\%$ \\
\hline Melakukan tidak sesuai & 5 & 16,7 & 7 & 23,3 & 12 & 40 \\
\hline Melakukan sesuai & 14 & 46,7 & 4 & 13,3 & 18 & 60 \\
\hline Total & 19 & 63,4 & 11 & 36,6 & 30 & 100 \\
\hline
\end{tabular}

Berdasarkan tabel 2 menunjukkan dari 30 responden yang melakukan senam yoga sesuai mengalami insomnia membaik sebanyak 14 responden (46,7\%). Sedangkan yang melakukan teknik senam yoga yang kurang sesuai mengalami insomnia membaik sebanyak 5 responden $(16,7 \%)$.
Selanjutnya responden yang melaksanakan teknik senam yoga yang sesuai mengalami insomnia yang memburuk sebanyak 4 responden $(13,3 \%)$. Sedangkan yang melakukan teknik senam yoga kurang sesuai mengalami insomnia memburuk sebanyak 7 responden $(23,3 \%)$

Tabel 3. Uji Korelasi Senam Yoga dan Insomnia di Kelompok Senam Yoga Asthma (Chi-Square Test)

\begin{tabular}{|c|c|c|c|c|c|}
\hline & Value & $\mathrm{df}$ & $\begin{array}{l}\text { Asymp.Sig. } \\
\text { (2 sided) }\end{array}$ & $\begin{array}{c}\text { Exact Sig. } \\
\text { (2-sided) }\end{array}$ & $\begin{array}{c}\text { Exact Sig. } \\
\text { (1-sided) }\end{array}$ \\
\hline Pearson Chie-Square & $4.043^{\mathrm{a}}$ & 1 & .044 & \multirow{6}{*}{.063} & \multirow{6}{*}{.052} \\
\hline Continuity Correction ${ }^{\mathrm{b}}$ & 2.638 & 1 & .104 & & \\
\hline Likelihood Ratio & 4.059 & 1 & .044 & & \\
\hline Fisher's Exact Test & & & & & \\
\hline Linear-by-Linear Association & 3.908 & 1 & .048 & & \\
\hline $\mathrm{N}$ of Valid Cases ${ }^{\mathrm{b}}$ & 30 & & & & \\
\hline
\end{tabular}

a. 1 cells $(0.0 \%)$ have expected count less than 5 . The minimun expected count is 5.40

b. Computed only for $2 \times 2$ table

Berdasarkan tabel 3, menunjukkan bahwa uji korelasi senam yoga dan insomnia melalui uji chi square didapatkan nilai Asymp. Sig. (2-sided) sebesar 0,044. Nilai Asymp. Sig. (2-sided) lebih kecil dari $\alpha=0,05$. Sehingga terdapat hubungan yang signifikan antara senam yoga yang dilakukan secara rutin dan insomnia.

Berdasarkan proses penghitungan penelitian yang dilakukan dari 30 responden yang melakukan senam yoga sesuai mengalami insomnia membaik sebanyak 14 responden (46,7\%). Sedangkan yang melakukan teknik senam yoga yang kurang sesuai mengalami insomnia membaik sebanyak 5 responden (16,7\%). Selanjutnya responden yang melaksanakan teknik senam yoga yang benar mengalami insomnia buruk sebanyak 4 responden $(13,3 \%)$. Sedangkan yang melakukan teknik senam yoga kurang sesuai mengalami insomnia memburuk sebanyak 7 responden $(23,3 \%)$.

Analisis gangguan tidur pada lansia disebabkan oleh berbagai faktor, baik itu fisik, psikologis, maupun mental. Gangguan tidur pada lansia salah satunya dipengaruhi kurangnya aktivitas fisik yaitu berolahraga. Kurangnya aktivitas fisik yang menyebabkan kesulitan tidur pada lansia. Pada otototot tubuh mengalami ketegangan sehingga lansia mengalami kesusahan tidur (Hafizah et al., 2018).
Latihan fisik atau yang dikenal dengan olahraga tindakan fisik untuk menguatkan kesehatan atau memperbaiki deformitas fisik, melakukan latihan fisik minimal 30 menit dapat menstimulasi pelepasan hormon endorfin dan menurunkan kadar hormon kortisol didalam tubuh dan menyebabkan keseimbangan mental. Salah satu jenis olahraga yang sering diaplikasikan adalah Yoga (Nurdianningrum and Purwoko, 2016).

Dalam Penelitian yang dilakukan terdapat fakta dan teori dimana yoga dapat mempengaruhi hipotalamus untuk meningkatkan produksi beta endorphin yaitu suatu morfin alami tubuh yang akan menyebabkan stabilitas emosi serta membuat rileks tubuh. Kondisi tenang dan rileks inilah yang akan mendorong lansia untuk memulai tidurnya sampai hingga masuk ke dalam fase tidur. Selain itu efek dari yoga adalah menurunkan ketegangan otot sehingga peredaran darah lancar, oksigen yang dibawa ke otak pun terpenuhi. Hal tersebut menunjang untuk memasuki fase tidur yang lebih dalam. Menurut peneliti, adanya kesesuaian antara teori dan praktek yang menyatakan bahwa yoga dapat memperbaiki pola tidur (Faidah, Bindhu and Sriadi, 2020). 
Dari hasil uji chi square dapat diperoleh bahwa nilai Asymp. Sig. (2-sided) sebesar 0,044 lebih kecil dari $\alpha$. Sehingga dapat ditarik kesimpulan terdapat hubungan antara senam yoga terhadap insomnia. Hal ini sejalan dengan penelitian yang dilakukan oleh Sisilia IndriasariW, Pengaruh Yoga Terhadap Kualitas Tidur Lansia (Elderly) mengatur keseimbangan sistem dalam tubuh. Suasana rileks menjadikan lansia dapat memusatkan pikiran sehingga stres yang bersifat negatif atau kurang mendukung bagi lansia dapat dialihkan walau hanya sementara, sehingga membuat lansia dapat segera tertidur (Amalia, 2017) (Faidah, Bindhu and Sriadi, 2020). Pada waktu lansia tertidur terjadi pelemasan otot dan penormalan sistem tubuh, sehingga sistem tubuh bisa kembali berfungsi efektif dan optimal yang dapat ditunjukkan dengan gejala dan tanda dari kondisi yang ditimbulkan pada saat tidur yang berkualitas, seperti mampu berkonsentrasi, memiliki hubungan sosial yang luas, tidak merasa pusing setelah bangun tidur dan lainlain (Chasanah, 2017) (Shoewu et al., 2016). Sehingga terdapat hubungan antara senam yoga dengan insomnia pada lansia. Penelitian ini memberikan implikasi untuk mahasiswa kebidanan sebagai informasi bahwa faktor kerutinan mengikuti senam yoga menjadi ukuran penting dalam mempengaruhi kualitas tidur lansia. Hal ini juga dapat menjadi sumber informasi bagi institusi pendidikan untuk mengembangkan metode pembelajaran agar mahasiswa lebih memahami faktor-faktor lain yang mempengaruhi kualitas tidur lansia.

\section{KESIMPULAN DAN SARAN}

Berdasarkan hasil penelitian, didapatkan bahwa terdapat hubungan antara terapi senam yoga dengan insomnia lansia. Senam Yoga yang dilakukan secara rutin dapat menurunkan insomnia yang dialami oleh lansia. Jadi, kerutinan mengikuti senam yoga merupakan faktor penting yang harus diperhatikan agar mendapatkan manfaat yang optimal dalam meningkatkan kualitas tidur lansia. Oleh karena itu, peneliti merekomendasikan kepada praktisi kesehatan untuk melakukan advokasi ke kelompok senam yang lainnya dalam memberikan solusi kepada lansia terlebih lagi terhadap posbindu yang belum menerapkan kegiatan senam yoga pada wilayahnya dan mendorong para lansia untuk mengikuti senam yoga secara rutin.

\section{REFERENSI}

Amalia, I. N. (2017) Hubungan Antara Kualitas Tidur dengan Kelelahan Fisik Lansia, Fakultas Ilmu Kedokteran Universitas Diponegoro.

Chasanah, N. (2017) 'Hubungan Kualitas Tidur Dengan Kualitas Hidup pada Lansia di Kelurahan Karangasem Kecamatan Laweyan Surakarta', Universitas Muhammadiyah Surakarta.

Faidah, N., Bindhu, I. P. B. M. and Sriadi, N. N. P. (2020) 'Pengaruh Latihan Hatha Yoga Erhadap Kualitas Tidur pada Lansia', Bali Medika Jurnal. doi: 10.36376/bmj.v7i1.117.

Hafizah, N. et al. (2018) 'Analisis Faktor yang Mempengaruhi Kualitas Tidur Pasien di Ruang Perawatan Intensive Care RSU Haji Surabaya', Sleep.

Ilmi, M. N., Saraswati, R. and Hartono (2019) 'Analisis Asuhan Keperawatan Gerontik dengan Masalah Keperawatan Utama Gangguan Pola Tidur dengan Senam Yoga di Desa Sidoharum Kecamatan Sempor Kabupaten Kebumen', University Research Colloqium.

Kamel, N. S. and Gammack, J. K. (2006) 'Insomnia in the Elderly: Cause, Approach, and Treatment', American Journal of Medicine.doi: 10.1016/j.amjmed.2005.10.051.

Kemenkes RI (2017) 'Analisis Lansia di Indonesia', Pusat data dan informasi Kementerian Kesehatan RI.

Luik, A. I. et al. (2015) 'REM sleep and depressive symptoms in a population-based study of middle-aged and elderly persons', Journal of Sleep Research. doi: 10.1111/jsr.12273.

Purnomo, W. and Bramantoro, T. (2018) 'Pengantar Metodologi Penelitian Bidang Kesehatan', Airlangga University Press.

S, I. (2019) 'Latihan relaksasi otot progresif terhadap kualitas tidur lansia', Jurnal Keperawatan.doi:10.32583/keperawatan.v11i 3.581 .

Selo, J., Candrawati, E. and Putri, R. M. (2017) 'Perbedaan Tingkat Stres Pada Lansia Di Dalam Dan Di Luar Panti Werdha Pangesti Lawang', Nursing News. 
Setiawan, I. W. A., Yunani and Eni, K. (2014) 'Hubungan Frekuensi Senam Lansia Terhadap Tekanan Darah dan Nadi pada Lansia Hipertensi', Prosiding Konferensi Nasional II PPNI Jawa Tengah 2014.

Shoewu, O. et al. (2016) 'Pengaruh Pola Tidur Sehat terhadap Tingkat Insomnia Lansia', CEUR Workshop Proceedings.

Sujarweni, V. W. (2015) Metodologi Penelitian, Jakarta: Rineka Cipta.

Sukmawati, N. M. H. and Putra, I. G. S. W. (2019) 'Reliabilitas Kusioner Pittsburgh Sleep Quality Index ( Psqi ) Versi Bahasa Indonesia Dalam Mengukur', Jurnal Lngkungan dan pembangunan.
Sutton, E. L. (2014) 'Insomnia', Medical Clinics of North America. doi: 10.1016/j.mena.2014.01.008.

Suzuki, K., Miyamoto, M. and Hirata, K. (2017) 'Sleep disorders in the elderly: Diagnosis and management', Journal of General and Family Medicine. doi: 10.1002/jgf2.27.

Wicaksono, D. W. (2019). 'Analisis Faktor Dominan yang Berhubungan dengan Kualitas Tidur pada Mahasiswa Fakultas Keperawatan Universitas Airlangga', Fundamental and Management Nursing Journal. doi: 10.20473/fmnj.v1i1.12131. 